\title{
Cahokia: Urbanization, Metabolism, and Collapse
}

\author{
Joseph A. Tainter* \\ Department of Environment and Society, Utah State University, Logan, UT, United States
}

Cahokia in the twelfth century A.D. was the largest metropolitan area and the most complex political system in North America north of Mexico. Its metabolism depended on an area of high natural and agricultural productivity. As it grew, Cahokia absorbed much of the rural population, transforming their labor from agriculture to public works. As Cahokia collapsed, this population first reoccupied the countryside, then left the region. Cahokia's sustaining area was largely abandoned until the nineteenth century. Factors pertinent to understanding the collapse of Cahokia include societal metabolism, complexity, level of public works, the status of the support population, and growth within the elite stratum.

Keywords: Cahokia, collapse, complexity, Mississippian, urban metabolism, urbanization

\section{OPEN ACCESS INTRODUCTION}

Edited by:

Sergio Ulgiati,

Università degli Studi di Napoli

Parthenope, Italy

Reviewed by:

Paul Charles Sutton,

University of Denver, United States

A. J. White,

University of California, Berkeley,

United States

Samuel Munoz,

Northeastern University, United States

${ }^{*}$ Correspondence:

Joseph A. Tainter

joseph.tainter@usu.edu

Specialty section:

This article was submitted to Urban Resource Management, a section of the journal

Frontiers in Sustainable Cities

Received: 16 August 2019 Accepted: 08 November 2019 Published: 03 December 2019

Citation:

Tainter JA (2019) Cahokia: Urbanization, Metabolism, and Collapse. Front. Sustain. Cities 1:6. doi: 10.3389/frsc.2019.00006
It is rare that we can study the full course of a city's life, from development to collapse and abandonment. Archaeologists have explored many cities, but those in the Near East, the Mediterranean Basin, and West Africa were largely covered by later occupations, so that much evidence has been destroyed. The site of Cahokia in the center of the United States was never built over by subsequent cities, so its history can be revealed. We know much of Cahokia's metabolism (the production, consumption, and processing of the resources on which an institution depends), establishment, growth, and end, as well as the collapse of the society that built it. Moreover, the development of Cahokia's sustaining area is sufficiently known to show how the center and the countryside evolved together.

There is much to be learned about Cahokia, but current knowledge places the settlement within the process of urbanization, and the recurrent process of societal collapse. Several past societies have collapsed (Tainter, 1988; Middleton, 2017), and a comparative discussion of such cases will show that the collapse of Cahokia can be clarified by understanding the costs and consequences of societal complexity.

Europeans who first encountered Cahokia found a landscape of earthen mounds, dominated by a multi-level structure which came to be called Monks Mound. Monks Mound is one of the largest earthworks ever built by prehistoric people (Figure 1). Beyond such impressive features, excavation reveals a settlement of houses, compounds, pits, palisades, and a circular structure termed a woodhenge (after England's famous Stonehenge). Within this area there is abundant evidence of Cahokia's metabolism. That metabolism changed with Cahokia's construction, so that the settlement's metabolism and political development evolved simultaneously.

\section{THE CAHOKIA SITE}

Cahokia was the most ambitious program of monumental construction and is today the largest archaeological site north of Native Mesoamerica. It was the first of a series of political centers that developed in the southeastern United States in what is called the Mississippian period 


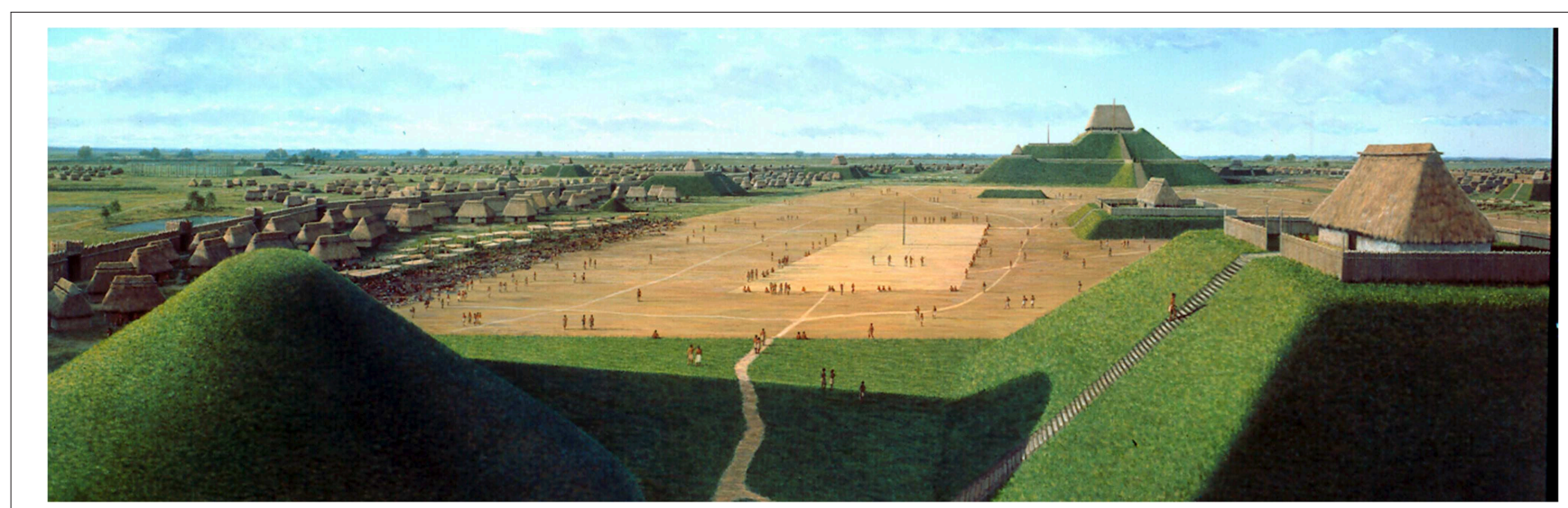

FIGURE 1 | A reconstruction of Cahokia. Mural by Lloyd Townsend.

(800-1600 A.D.) (Figure 2), and it exceeded all later ones in size, volume of public works, complexity, and territorial reach (Anderson, 1994; Muller, 1997).

Cahokia is a product of both hierarchical planning and vernacular expediency. It covers an area of about 14 square kilometers (Pauketat, 1994, p. 5) but its boundaries are unclear (Figure 3). Across a traverse of ten kilometers from Cahokia west to the St. Louis Mound Group, there is evidence of continuous settlement and mound construction (Emerson, 1997b, p. 46).

Monks Mound is an earthen structure of several tiers measuring 291 by $236 \mathrm{~m}$ and $30 \mathrm{~m}$ high. Its 615,000 cubic meters of fill rank it behind only the Pyramid of Cholula and the Pyramid of the Sun at Teotihuacán among the largest structures in prehistoric North America (Fowler, 1969, p. 1; Pauketat and Emerson, 1997, p. 11). Monks Mound sat among 120 mounds, which originally comprised much of the public architecture of the site, which vary in form and function, and which were built or added to through nearly the entire period from 1050 to 1300 A.D.

The central precinct of the site, organized around Monks Mound, was from the start conceived, planned, and built to create a large and impressive public space (Figures 1, 3) (Milner, 1991, p. 32, Dalan, 1997; Milner, 1998, p. 100; Dalan et al., 2003). Monks Mound is flanked by plazas on all four sides with the largest-the 19-hectare "Grand Plaza"-extending outward from Monks Mound's southern ramp. The Grand Plaza and other public structures nearby formed the focus of public life, elite activity, ritual, and the political organization of both town and countryside.

Mounds and the structures atop them were clearly the major elements of public architecture. There were more than 200 of them from Cahokia to St. Louis to the west (Figure 4) (Pauketat and Emerson, 1997, p. 8) but labor was organized to build other public structures as well. Perhaps the most curious is a series of post-and-circle monuments (originally and incorrectly called "woodhenges") constructed to the west of Monks Mound. Four of these are known, of which the most completely excavated has a diameter of $126 \mathrm{~m}$ (Pauketat and Emerson, 1997, p. 14).
Sometime after their construction, Monks Mound and the Grand Plaza were enclosed by a great palisade. It runs for about $3.2 \mathrm{~km}$. and encloses an area of roughly 120 ha (Fowler, 1989, p. 195-197; Emerson, 1997a, p. 45). The palisade featured bastions every $20 \mathrm{~m}$ as well as screened entrances. Like the post-and-circle monuments, the palisade was built and rebuilt four times, with about 20,000 logs going into each construction (Pauketat, 1994, p. 91).

Flanking the public space of the Grand Plaza there were smaller mounds, plazas, and residential areas. These do not appear to have been established according to an overall conception or plan. Rather they form a complicated amalgamation of subcommunities or neighborhoods. These subcommunities may have consisted of kin-based social groups (Milner, 1991, p. 32). In these groupings, which show their own internal organization, resided the people who no doubt formed much of the labor force for public constructions.

\section{ENVIRONMENT}

Cahokia is located in an area called today the American Bottom. It begins on the north at the confluence of the Illinois, Mississippi, and Missouri rivers and ends on the south at the confluence of the Kaskaskia River (Figure 5). In the early ninetieth century it was a floodplain containing sloughs, oxbow lakes in former river channels, forests, long ridges interspersed with wet swales, and occasional large, dry areas (Emerson, 1997b, p. 249). At the beginning of the historic era the American Bottom was not heavily wooded, but that may be a consequence of the late prehistoric occupation.

The American Bottom is a land dominated by water, which tends perniciously to occur either too much or too little, at the wrong time, or in the wrong place. Before historic flood control much of the American Bottom below $125 \mathrm{~m}$. elevation was inundated either seasonally or year-round. In both the late prehistoric period and recently, land use above $125 \mathrm{~m}$. elevation was comparatively secure. Both prehistoric and historic use of the bottom was greatly constrained by this. In one study area south 


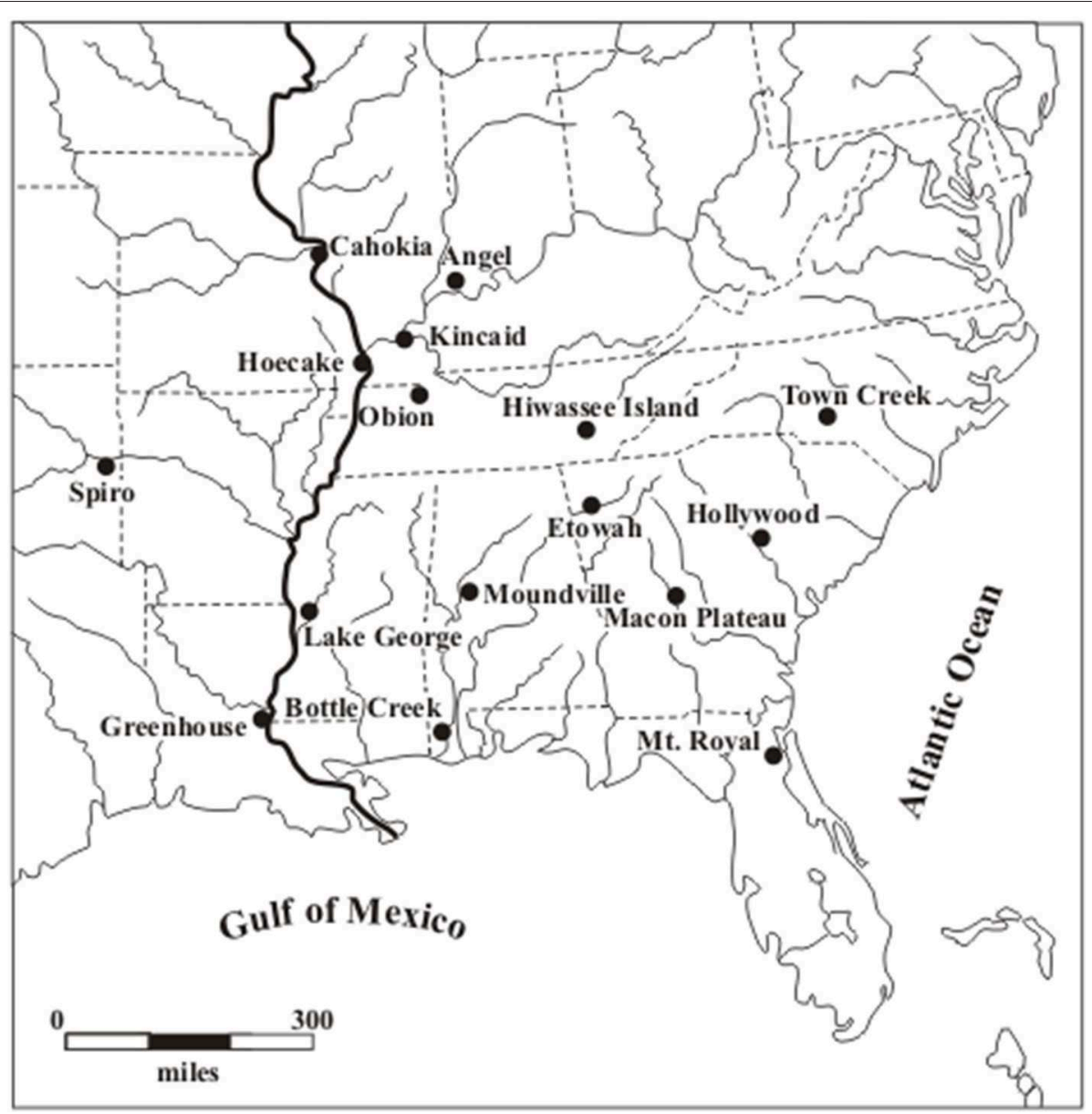

FIGURE 2 | Mississippian Sites in the Southeastern United States (after Pauketat and Emerson, 1997: Figure 1.1).

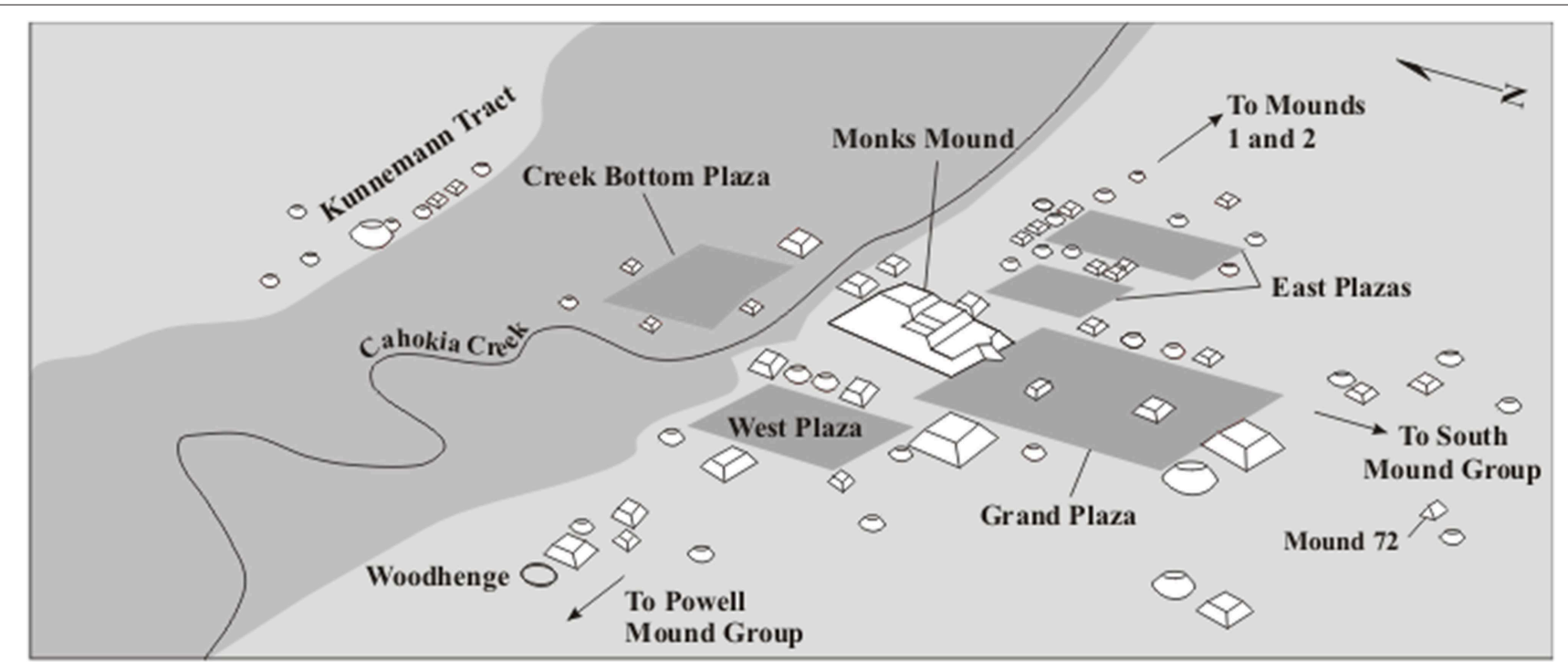

FIGURE 3 | Central Cahokia (after Pauketat and Emerson, 1997: Figure 1.5). 


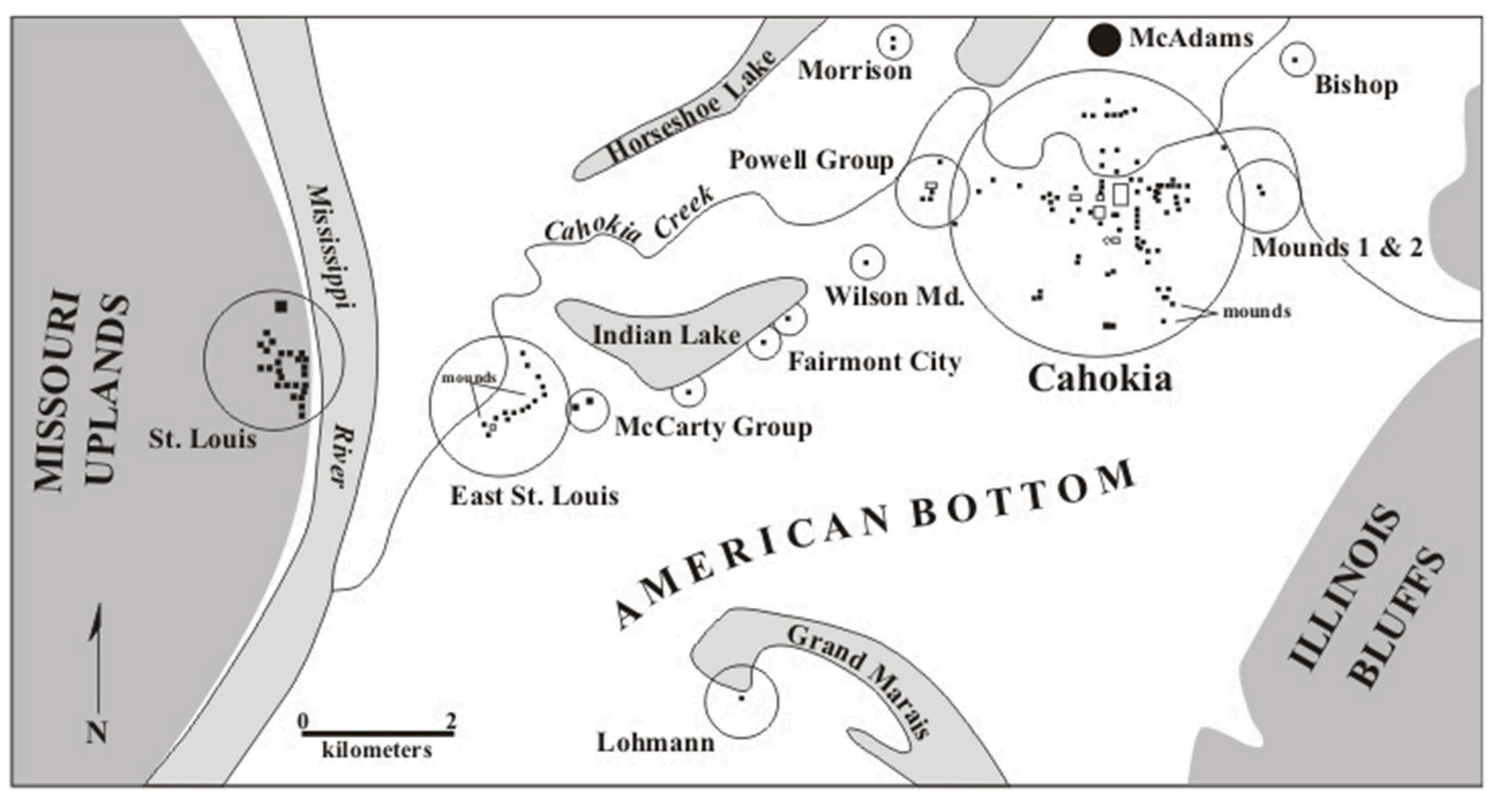

FIGURE 4 | The northern American Bottom (after Pauketat and Emerson, 1997: Figure 1.2).

of Cahokia only $37 \%$ of land was found to lie above this elevation (Milner, 1986, p. 229; Milner, 1991, p. 33). The American Bottom around Cahokia is bounded by bluffs on the east (Figure 4), which were the habitat of trees bearing nutritious nuts, and the Mississippi River on the west.

Within this area, Cahokia is situated on higher ground than other locations, near periodically enriched, well-drained soils. Within a five $\mathrm{km}$. catchment around Cahokia there is the largest zone in the area that is optimal for cultivating with stone hoes. Other locations also had these advantages, but Cahokia had more of them (Dalan et al., 2003).

\section{Political Development}

Five archaeological phases (culturally distinct time periods) are pertinent to understanding Cahokia: Emergent Mississippian, ca. 925-1050 A.D.; Lohmann, ca. 1050-1100; Stirling, ca. 1100-1200; Moorehead, ca. 1200-1275; and Sand Prairie, ca. 1275-1350 (Table 1) (Hall, 1991).

\section{Emergent Mississippian Phase, ca. 925-1050 A.D.}

Environmental data reveal that centuries before the building of Cahokia, the American Bottom was already an anthropogenic landscape. By around 450 A.D. there was rapid deforestation of both the floodplain and the uplands (Munoz et al., 2014, p. 501; White et al., 2019). Agricultural development seems to have reached a peak just prior to Cahokia's emergence as a political center (Munoz et al., 2014, p. 501). Lakes were polluted and filled with algae (Brugam and Munoz, 2018, p. 453).

The decades leading up to 1050 witnessed a growing population (Pauketat, 1997, p. 31). Village size increased through time (Emerson, 1997b, p. 256), as did the diversity of building forms and the complexity of community configuration (Pauketat, 1994 , p. 52). Houses were arranged around central courtyards
(Pauketat, 1994, p. 51), and social groups in rural villages practiced communal storage and used communal buildings (Mehrer, 1995, p. 139-140).

By late in the Emergent Mississippian period there were formal towns with central plazas, high and low status residences, and large population clusters (Emerson, 1997a, p. 176). In the late tenth century one of these villages, the Range site, may have had 100 structures (Pauketat, 1994, p. 52). Temple mound construction is postulated to have begun at this time, but none has so far been found (Emerson, 1997a: 176).

The political environment was changing as well. By 1000 A.D. the American Bottom may have held a half-dozen civicceremonial centers, each the focus of a complex chiefdom (Emerson, 1997a, p. 187; Emerson, 1997b, p. 58). Within this political landscape, Cahokia by the early eleventh century was already a large and expanding community, home to perhaps 1,400 people or more. A chiefly center already, its layout and features at this time appear very much like its contemporary settlements (Pauketat and Emerson, 1997, p. 5; Pauketat, 1997, p. 31). Houses here, as elsewhere, were organized around courtyards (Pauketat, 1994, p. 180), and courtyard groups seem to have been the basic social unit (Mehrer, 1995, p. 156).

Cahokia appears to have emerged during a dry period (Munoz et al., 2015), which is significant for rain-fed agriculture. Even so, we see in the decades before 1050 an expanding population based on farming and foraging, the development of increasingly large, complex communities, and the emergence of rank differences, chiefly hierarchies, and a competitive political environment. Then, in the years around 1050 A.D., American Bottom society was transformed to such a degree that it was reconstituted on its most basic elements. The Lohmann phase, rather than culminating the Emergent Mississippian, can more accurately be said to have revolutionized it. 


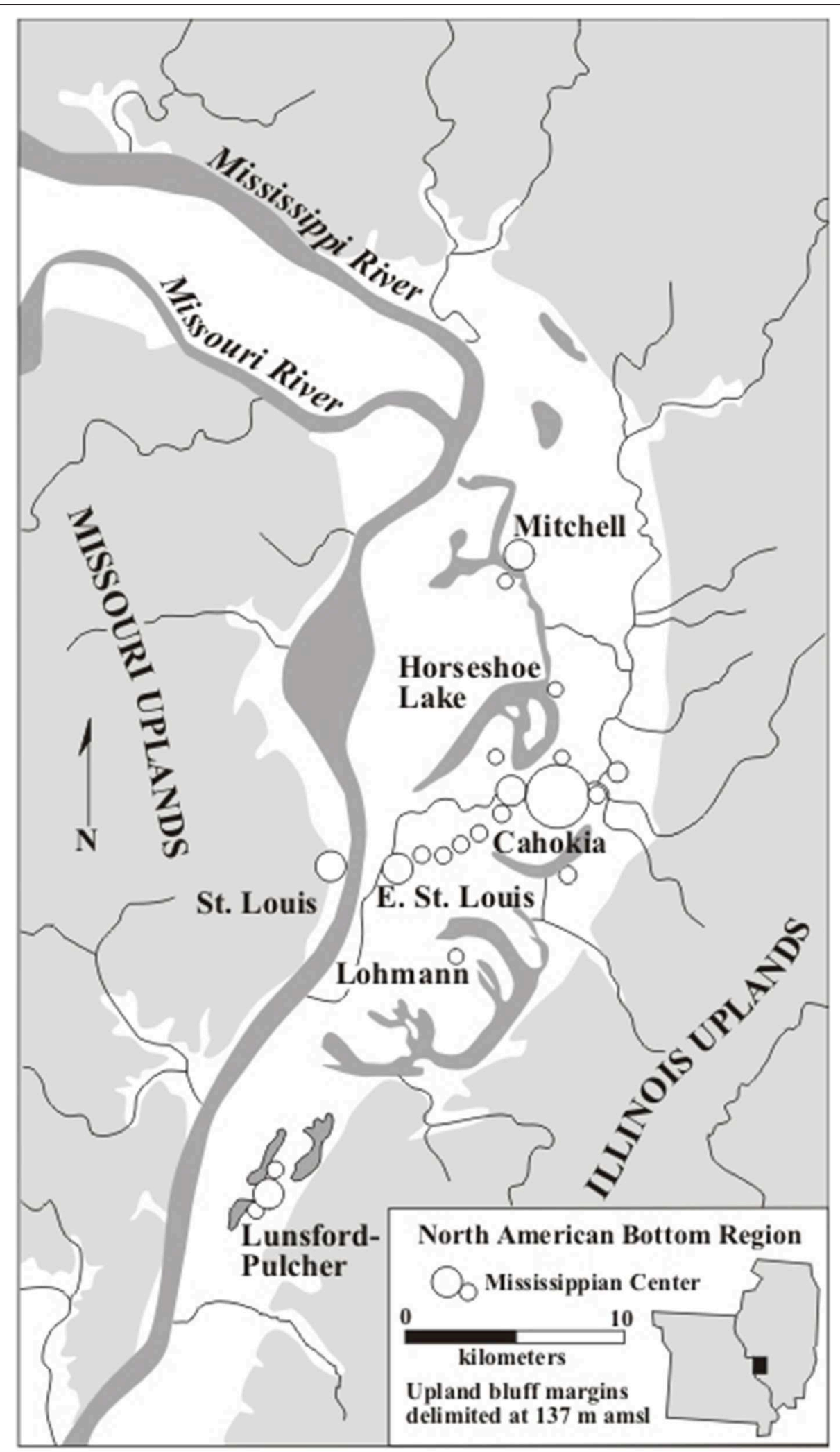

FIGURE 5 | Mound groups in the Cahokia area (after Pauketat and Emerson, 1997: Figure 1.4). 
TABLE 1 | Mississippian phases in the American bottom.

\begin{tabular}{lr}
\hline Phase & Time span \\
\hline Emergent Mississippian & $925-1050$ A.D. \\
Lohmann & $1050-1100$ A.D. \\
Stirling & $1100-1200$ A.D. \\
Moorehead & $1200-1275$ A.D. \\
Sand Prairie & $1275-1350$ A.D. \\
\hline
\end{tabular}

\section{Lohmann Phase, ca. 1050-1100 A.D.}

Timothy Pauketat refers to the events of ca. 1050 as "...the political and economic equivalent of the Big Bang” (1997, p.31; 2004). It was a time that witnessed the first large-scale appearance of elite-associated architecture, monuments, cult symbolism, and mortuary patterns reflecting extraordinary Cahokian power (Emerson, 1997b, p. 190). A great pit dug over 37,000 square meters of surface to provide soil for building mounds may have been started just prior to 1050 (Dalan, 1997, p. 93). Parts of the Cahokia community that had been residential were commandeered for ceremonial and elite use. The alignment of the civic and religious center was established (Emerson, 1997b, p. 48), giving the impression that the scale and layout of the site's core were envisioned from the start (Dalan, 1997, p. 100). The large, central plazas were probably established at the start of the Lohmann phase (Pauketat and Emerson, 1997, p. 7). Early construction focused on both the Grand Plaza and Monks Mound (Figures 1, 3). Other early mounds were themselves focused on the political and ritual center formed by this commanding edifice and the great public space before it. Monks Mound was completed to nearly its final form by at least 1200 A.D., but may actually have achieved much of this form by 1100 (Dalan, 1997, p. 98). This would have been done in a construction period of only 50 years.

Cahokia from the outset produced strong centripetal forces. The upland areas adjacent to the American Bottom (Figure 5) had previously supported a sizeable agricultural population. Beginning with the Lohmann phase these uplands were substantially depopulated. These people apparently moved into the bottomland (Harn, 1971; Munson, 1971; Woods and Holley, 1991, p. 59), many probably to Cahokia itself (Pauketat, 1994, p. 174). Cahokia's population correspondingly grew by five to ten times (Pauketat and Emerson, 1997, p. 5), and the transformation appears archaeologically to have been quite rapid. From a late Emergent Mississippian population estimated at 1400 to 2800 , there was an explosion to between an estimated 10,200 and 15,300 (Figure 6) (Pauketat and Lopinot, 1997, p. 115-116). Large new residential areas would have had to be prepared for these people, and they would have had to develop new social relations among themselves (Mehrer, 1995, p. 157; Pauketat, 1997, p. 38; Collins, 1997, p. 126-128).

North America north of Mexico had never experienced a community of 10,000 to 15,000 people. Many of the immigrants no doubt went to work on the new public monuments and spaces, and would have needed to be subsidized in many of their daily needs. It is estimated that the five-kilometer catchment around

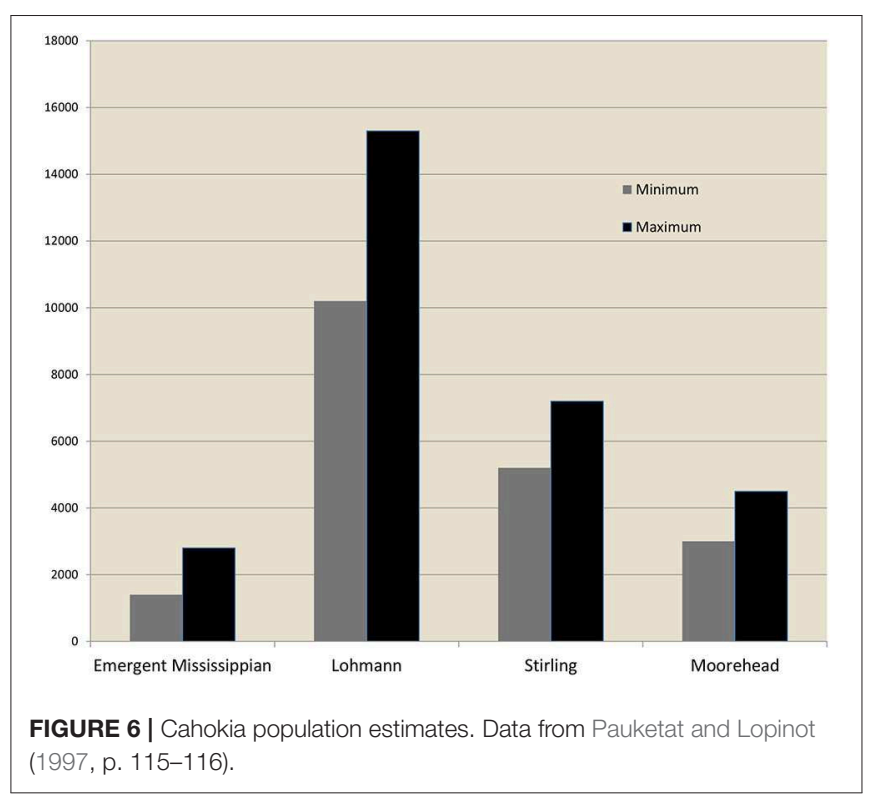

Cahokia could have supported about 7,500 to 12,000 people (Emerson, 1997b, p. 154). It is thus likely that at least some of the 10,000 to 15,000 people of Lohmann-phase Cahokia would have had to be subsidized by production further away.

For those who remained in the countryside life changed quite as dramatically. Rural social structure and relations were utterly transformed. The growing villages of the Emergent Mississippian period disappear from the archaeological record. A settlement known as the Range site, for example, which in the decades leading up to 1050 had held up to 100 structures, was reduced to 4 homesteads in the Lohmann phase. The rural population dispersed across the countryside, and most sites of the period were occupied by single households. At the same time, as many people moved to Cahokia, rural population density declined in the last half of the eleventh century (Milner, 1990, p. 28; Emerson, 1997a: 187; Emerson, 1997b: 256; Pauketat, 1994, p. 74; Pauketat and Lopinot, 1997, p. 119; Mehrer, 1995, p. 142). Thus, to support the great public undertakings at Cahokia and other mound centers, those left in the countryside would have needed greatly to intensify their production. As argued below, the rural population supporting the metropolis would have needed to farm on less desirable land than Cahokia itself occupied (Dalan et al., 2003, p. 85; Barthel et al., 2019), with an increase in the cost of transporting food. Cahokia was built at a cost of demonstrably higher labor per capita.

We see in the Lohmann phase a dissolution of village life that was drastic and abrupt. Given the power clearly held by Cahokia's rulers, it may be accurate to say that village life was deliberately terminated. Such an action would have come from the highest levels. The community bonds of coresidence and sharing were broken, and thereafter Mississippian commoners began increasingly to store food inside their houses rather than communally. Whether or not this transformation was engineered by the elites it was greatly to their advantage. By breaking traditional horizontal ties the elites both eliminated alternative 
dimensions of organization and created a vacuum in social relations that was filled by reordering society along vertical lines. Hereafter isolated homesteads owed their primary allegiance less to their peers and more to often-distant elites.

Some authors see evidence in the Lohmann phase for the development of a settlement type intermediate between mound centers and isolated households. These are termed "nodal sites" and contain community houses, low-level elite mortuary facilities, communal storage, and specialized political and religious structures (Pauketat, 1994, p. 73; Emerson, 1997a, p. 176, 178, Emerson, 1997b, p. 60, 78; but see Mehrer, 1995, p. 158). These sites are, however, more evident in the subsequent period.

One feature at Cahokia, Mound 72, illustrates the dramatic Lohmann-phase transformations in political development, the scale of community integration, the extent of landscape planning, and the degree of elite power. Mound 72, excavated by Melvin Fowler, lies about $800 \mathrm{~m}$ south of Monks Mound and seems to have had a role in architecturally anchoring the central portion of the community (Fowler, 1969, p. 19; Fowler, 1989, p. 151, Fowler, 1991, p. 5-9, Young and Fowler, 2000). The initial features, before there was a mound, were two large posts. They measured nearly a meter each in diameter and would have stood to a commensurate height. The southeastern post was replaced at least three times, and in time both were permanently removed. After the posts were removed a primary mound was built over the location of each. A third, larger primary mound was added between them, then a ridge-shaped mound was constructed to cover all three. At this point Mound 72 achieved its final form.

Submound 1 was built over an adult male buried on an extroardinary platform of shell beads. With him were four other individuals buried apparently contemporaneously. It is no exaggeration to call them retainers, for his burial apparently triggered theirs. They were interred with a panoply of exotic goods, including polished stones called discoidals, shell beads, a long tube of rolled copper, and hundreds of arrows grouped in bundles, the stone points of which were fashioned to an extraordinary degree of refinement.

Submound 2 contained an extended burial placed over what had been a charnel house. Along with both primary and bundle burials there were three large pits that included both burials and offerings. The third, intermediate submound was built over a pit containing 53 females aged 18 to 25 . Nearby were four males whose heads and hands had been removed. Along the southwest margin of the burial mound there was a series of rectangular pits. The most elaborate of these had two layers of burials, the lower a jumble of 39 individuals, mostly male, three of whom had been decapitated, and two of whom had arrowheads in their chest or vertebrae. The upper layer had ten individuals placed carefully in a line, who had been transported on litters carried by cedar poles (Fowler, 1969, 1991; Pauketat, 1997, p. 34; Emerson, 1997b, p. 48; Young and Fowler, 2000). The sacrificed young women in Mound 72 had poor health, and had experienced nutritional stress (Ambrose et al., 2003, p. 217). This, coupled with their execution, indicates that they were slaves.

While it is tempting to see the apparent sacrifice of these individuals as part of ceremonies attending the construction of the mound, one point is beyond dispute: the rulers of Cahokia had the power to command the execution of scores of individuals. There is no precedent for this in the prehistory of the area. Although we can never be certain that the Cahokian elites deliberately destroyed rural village organization and enforced dispersal into isolated households, the evidence of Mound 72 suggests that it was in their power to do so.

\section{Stirling Phase, ca. 1100-1200 A.D.}

The Stirling phase represents the apex of Cahokia's political evolution. Across the northern American Bottom there is a homogeneity of material culture which suggests integration of the entire region (Emerson, 1997b, p. 51; Pauketat and Emerson, 1997, p. 8). At Cahokia itself the lives of the most powerful were organized around the Grand Plaza, which reached roughly its final form by late in the period. A structure atop Monks Mound covering 400 to 800 square meters would seem to have been the residence of the paramount (Kelly J. E., 1997, p. 141, 164).

Cahokia experienced a flurry of construction during the Stirling phase. Monks Mound was essentially completed but there was extensive mound building on other parts of the site (Emerson, 1997b, p. 51). At both Cahokia and East St. Louis new construction tended to occur at the edges of areas where public architecture was previously built (Kelly J. E., 1997, p. 165). Thus, the core areas of both sites were expanding. The Stirling phase yields the first accepted evidence of craft specialization at the site, based on concentrations of marine shells and the microdrills used to work them (Emerson, 1997b, p. 51).

Surprisingly, this continuing high level of construction at Cahokia was sustained by a declining population. From the Lohmann phase high of 10,200-15,300, Stirling phase population is estimated to have dropped to between 5,200 and 7,200 (Figure 6) (Pauketat and Lopinot, 1997, p. 116). The reduction in population, on the order of 50 percent, coincides with both an increase in the ritual and elite use of central Cahokia, and a shift in the organization of non-elite space. Areas that had been residential during the Lohmann phase became open plazas during Stirling. At one extensively-excavated area (ICT-II), early Stirling-phase households clustered around a large plaza that had formerly held Lohmann-phase residences. Late in the twentieth century a large, low-profile mound was built to the south of this subcommunity, and probably occupied by intermediate elites (Collins, 1997, p. 128-130). Ultimately, at least $1 / 3$ of the population of the American Bottom during the Mississippian period came from outside the area (Slater et al., 2014).

The countryside continued to experience changes, although these were not nearly so wrenching as those of a few generations before. Dispersed homesteads continued to be the dominant human feature of the landscape. There is fresh evidence for a settlement hierarchy of three tiers, with the occupants of dispersed homesteads organized locally around the larger and more complex nodal sites. These display one or more mounds, four to six structures used for both domestic and community functions, sweat houses, and mortuary facilities. They were often placed on a high, centrally-located spot in a system of ridges and may contain quite extraordinary ritual objects. Thomas Emerson sees in these sites evidence for the emergence of specialized ritual 
and civic functionaries through which the rural population was further controlled (Emerson, 1997a, p. 178-184, Emerson, 1997b, p. 78, 258).

Thus to some degree power seems to have diffused outward during the Stirling phase, and population did as well. For as the population of Cahokia declined that of the countryside grew. The Stirling phase rural population increased over that of Lohmann by as much as 53\% (Figure 7) (Milner, 1986, p. 232-233). By 1150 a group of settlements termed the Richland Complex had been established in the uplands east of Cahokia (Alt, 2002; Pauketat, 2003). Clearly population dispersed outward from Cahokia, but the reason why and the consequences are not fully known. Construction at Cahokia, and thus the demand for labor, continued at a high level in the Stirling phase. We may consider that the high level of nucleation in the Lohmann phase proved unsupportable, or unsupportable at a reasonable cost, and so labor was released back to the countryside for agricultural production. Those remaining at Cahokia would have been forced to undertake even greater efforts per capita in public construction, or labor forces would have had to be brought temporarily from the countryside. The latter option would have presented scheduling problems, for the most suitable time of year for constructing public monuments-when the ground is dry and unfrozen-corresponds to the agricultural labor season.

With the exception of Monks and Powell mounds, most early mounds at Cahokia, as noted, were comparatively small. During the Stirling phase construction was begun on a set of mounds that were substantially larger (Dalan, 1997, p. 99). By the end of the Stirling phase and into the Moorehead phase these mounds attain a size that Kelly describes as "massive" (Kelly J. E., 1997, p. 165). Rather than thin, incremental episodes of mound accretion, the additions became much greater and may have been established over longer periods of time.

The Stirling phase was also the time when the post-andcircle monuments (woodhenges) were built-and rebuilt at least three times. The first construction of the Great Palisade (Figure 1) began late in the period, with three successive

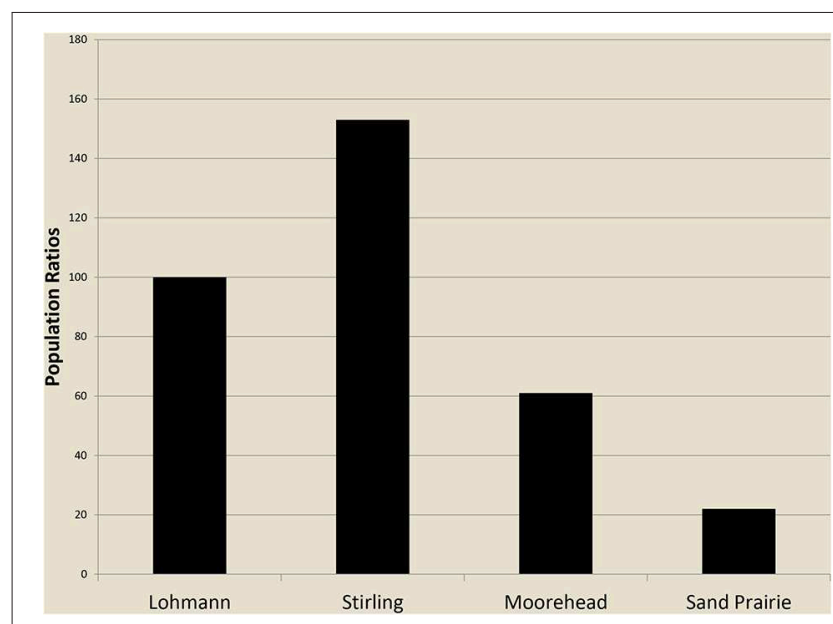

FIGURE 7 | Rural population indices, northern American Bottom (Lohmann Phase $=100$ ). Data from Milner (1986, p. 232-233). rebuildings extending into the Moorehead phase (Pauketat, 1994, p. 91). In these monuments we see a higher level of planning and engineering in public construction, and correspondingly a greater component of esoteric knowledge.

The Stirling phase paradoxically yields evidence of both the height of Cahokia's power and the beginning of its downfall. The picture that emerges of Stirling-phase Cahokia is of a polity at the peak of its power, engaging in ambitious public works at a sustained level, and tightening its grip on the countryside through a set of intermediate integrative centers. Yet in the formation of these centers we also perceive a diminution of Cahokia's power, which was premonitory if slight. This diffusion of power is reflected in the initial disaggregation of Cahokia itself and the dispersal of half its population to the countryside. Though these people must nominally have remained under central authority they were no longer subject to day-to-day control. In their absence those remaining at Cahokia again assumed greater labor burdens than before.

\section{Moorehead Phase, ca. 1200-1275 A.D.}

The apparently frequent rebuilding of the palisade well into the Moorehead phase-more often than would seem necessary from normal decay-suggests that the elites of this time could still assemble labor forces for public works. This impression is reinforced by continued construction elsewhere at the site. Monks Mound during the Moorehead phase acquired only some finishing touches-aprons and secondary mounds-but construction began on several other comparatively large mounds (Dalan, 1997, p. 101; Kelly J. E., 1997, p. 165). The Moorehead phase saw the peak demands for labor, even as population declined (Milner, 1998, p. 149).

Cahokia's population continued to decline in the Moorehead phase. From a Stirling phase population of between 5200 and 7200 , occupancy of the site dropped to between 3000 and 4500 (Figure 6). This represents a drop of 38\% from the Stirling phase and $71 \%$ from the Lohmann population maximum (Pauketat and Lopinot, 1997, p. 116). The population of Cahokia at this time was larger than that of the pre-Big Bang Emergent Mississippian by only about 60 percent. A population $60 \%$ larger looks impressive at first glance, but it represents only 1,600 to 1,700 people. By the estimate of William Iseminger (Pauketat and Lopinot, 1997, p. 104), the palisade alone required a labor force of 2,000-4,000 each time it was rebuilt.

Unlike the Stirling phase, the Moorehead population decline at Cahokia cannot be attributed to the release of labor to the countryside. The rural population of the thirteenth century declined also, and it did so quite as dramatically (Figure 7). George Milner sees a population decline on the order of $61 \%$ (1986, p. 232-233). Indeed the Moorehead phase population of the American Bottom dropped even below that of the Lohmann phase, to about $61 \%$ of its level of 100 to 150 years previously. It is not surprising to find that the demographic geography of the American Bottom underwent a complete reversal, with Cahokia's influence changing from centripetal to centrifugal. People were voting with their feet and Cahokia's elites, who once held the power of life and death, could no longer enforce the allegiance of their subjects. 


\section{Sand Prairie Phase, ca. 1275-1350 A.D.}

Both the Moorehead and Sand Prairie phases are poorly represented in rural areas. All of the specialized rural elites and their facilities disappeared quickly. There is no further evidence of the settlement hierarchy (Pauketat and Emerson, 1997, p. 8). Organization decentralized and came once again to be based on kinship and community. There was no longer an architecture of power and mortuary practices reveal an egalitarian organization. By the Sand Prairie phase there is little archaeological record at all except for isolated households and community cemeteries (Emerson, 1997a, p.188; Emerson, 1997b, p. 260). Sand Prairie phase population in the countryside declined a further $63 \%$ from the Moorehead phase and $85 \%$ from the Stirling phase maximum (Figure 7) (Milner, 1986, p. 232-233).

During the Moorehead and Sand Prairie phases at Cahokia the central precinct reverted to residential use. The post-and-circle monument was removed and the area west of Monks Mound reverted to habitation. Some mounds continued in use but the elites had lost the ability to enforce the core site plan. Cahokia by the late thirteenth century was still fixed in the landscape as a sacred place but as a polity it had collapsed (Mehrer, 1995, p. 160; Milner, 1990, p. 31-31; Milner, 1991, p. 36; Pauketat, 1997, p. 49).

\section{METABOLISM}

Maize began to be domesticated in Mexico about 9,000 years ago, and made its way to the American Southwest (the state of New Mexico) by 4,000 years ago. It became a staple cultigen there during the last few centuries B.C. At the time of European contact, people practicing agriculture in North America commonly cultivated maize. As a consequence, American Indian agriculture is commonly associated with maize. In the American Bottom, however, major dependence on maize came late. Although productive, maize is not a nutritious food. The fact that it was adopted rather late is attributable to the superior dietary value of native plants producing oily and starchy seeds. Here agriculturalists commonly cultivated a suite of local plants, producing what is called the Eastern Agricultural Complex. This consisted of such plants as bottle gourd, eastern gourd/squash, sunflower, marshelder or sumpweed, giant ragweed, chenopod, maygrass, erect knotweed, little barley, and tobacco (Fritz, 2019, p. 30).

Some plants of the Eastern Agricultural Complex had long been domesticated by the time Cahokia was built. Sunflower had been cultivated by 2900 B.C., Marshelder from 2400 B.C., and Ragweed by 2000 B.C. (Fritz, 2019, p. 20-24). Forests with nut-bearing trees had been managed by fire since at least 1200 B.C. (Fritz, 2019, p. 17). Maize appeared by 900 A.D., but was not initially a major part of the complex of domesticates (Fritz, 2019, p. 9).

Upon excavation, Mound 51, on the east side of the Grand Plaza, was found to be overlying the spectacular remains of several large feasts. Beneath the mound was a large pit, first excavated to provide fill for mound construction, measuring 19 by $59 \mathrm{~m}$., and about $3 \mathrm{~m}$. deep. Between 1050 and 1100 A.D. the pit was filled during a variety of episodes. Massive amounts of food remains and artifacts were deposited in successive layers, which are interpreted as the remains of large-scale feasts (Kelly, 2001; Pauketat et al., 2002; Fritz, 2019, p. 74-83). The plant remains from this location are rich and diverse, as apparently was the Cahokian diet. There are 50 taxa of plants, of which at least 30 were definite or probable foods (Pauketat et al., 2002, p. 265) (Table 2). Such diversity is important for food producers. Should some crops fail, others could make up the shortfall. It is unlikely that all would fail at once. As has been found at domestic contexts at Cahokia, there is under Mound 51 a low density of maize and a high density of starchy seeds such as maygrass (Pauketat et al., 2002, p. 272-273).

Late in Cahokia's occupation, plant food diets changed. People who had relied on the diverse plant foods of the Eastern Agricultural Complex came to depend heavily on maize (Fritz, 2019, p. 127-128). The significance of this development will be discussed below.

Like most people until recent times, the people of the American Bottom depended primarily on plant foods. Animal food was consumed in lesser amounts. Even so, as with cultivated plants, an impressive variety of animals was used (Table 3). In the Lohmann phase there were dramatic changes. Fish, always a staple food, went from $77 \%$ of animal remains to $10 \%$. Mammals, conversely, went from 10 to $67 \%$, mainly due to an increase in deer remains (Deer meat came from a distance from Cahokia, most likely from the eastern bluffs). Bird remains also increased, so that animal use overall continued to be heavily aquatic (Kelly L. S., 1997, p. 73-79).

In the Stirling phase, elites had greater access than the rest of the population to hindquarters of deer, a higher quality part. Elites at this time may also have been eating more terrestrial birds (turkeys and prairie chickens) than the rest of the population. Overall the elites would have been provisioned by those lower in rank (Kelly L. S., 1997, p. 69, 81). In the Moorehead phase, as people dispersed to the countryside, animal use became more localized. There was a decrease in mammal and bird remains, and an increase in fish. The less desirable parts of deer were consumed in greater quantities (Kelly L. S., 1997, p. 81-87). These changes in diet coincided with the major changes in political and territorial organization described earlier.

Not only did diet change during Cahokia's occupation, so did the area where food was grown. A cluster of farming villages was deliberately established in the uplands, $15-40 \mathrm{~km}$. southeast of Cahokia. These settlements date to the Lohmann and early Stirling phases (1050-1150 A.D.). Milner (1998, p. 74) suggests that the immediate environment of Cahokia could have supported only about 8,000 people. It was necessary to bring food from more distant areas to feed the estimated 10,000 to 15,000 residents of Lohmann phase Cahokia. Termed the Richland Complex, this occupation began and ended abruptly. This group of villages appears to have been established by Cahokia's rulers to satisfy the nutritional needs of the metropolis (Alt, 2002; Pauketat, 2003). These settlements were abandoned late in Cahokia's occupation.

As with the large variety of foods produced for the residents of Cahokia, the production of food in both bottomland and upland environments would have enhanced the security of the 
TABLE 2 | Plant remains from below Mound 51 (after Fritz, 2019, p. 76-77).

\begin{tabular}{|c|c|}
\hline Common name & Scientific name \\
\hline \multicolumn{2}{|l|}{ Nutshell } \\
\hline Thick hickory & Carya spp. \\
\hline Thin hickory/pecan & Carya spp.including C. illinoiensis \\
\hline Black walnut & Juglans nigra \\
\hline Walnut family & Juglandaceae \\
\hline Hazelnut & Corylus americana \\
\hline Acorn & Quercus sp. \\
\hline \multicolumn{2}{|l|}{ Fruit Seeds } \\
\hline Persimmon & Diospyros virginiana \\
\hline Strawberry & Fragaria virginiana \\
\hline Plum/cherry & Prunus spp. \\
\hline Bramble berry & Rubus sp. \\
\hline Black nightshade & Solanum cf. ptycanthum (formerly S. americanum) \\
\hline Grape & Vitis sp. \\
\hline Elderberry & Sambucus canadensis \\
\hline Mulberry & Morus sp. \\
\hline Blackhaw & Viburnum cf. prunifolium \\
\hline \multicolumn{2}{|l|}{ Crops } \\
\hline Corn & Zea mays spp. mays \\
\hline Squash (eastern) & Cucurbita pepo ssp. ovifera var. ovifera \\
\hline Squash (cushaw) & Cucurbita argyrosperma ssp. argyrosperma \\
\hline Bottle gourd & Lagenaria siceraria \\
\hline Tobacco & Nicotiana sp. \\
\hline Maygrass & Phalaris caroliniana \\
\hline Chenopod & Chenopodium berlandieri ssp. jonesianum \\
\hline Erect knotweed & Polygonum erectum \\
\hline Little barley & Hordeum pusillum \\
\hline Sunflower & Helianthus annuus var. macrocarpus \\
\hline Sumpweed & Iva annua \\
\hline \multicolumn{2}{|l|}{ Other Economic Food } \\
\hline \multicolumn{2}{|l|}{ Plants } \\
\hline Panicoid grasses & Panicum, Setaria, or close relative \\
\hline Amaranth & Amaranthus sp. \\
\hline Wild bean & Strophostyles helvola \\
\hline \multicolumn{2}{|l|}{ Other seed types } \\
\hline Aster family & Asteraceae \\
\hline Chenopod (weedy) & Chenopodium spp. \\
\hline Spurge & Euphorbia spp. \\
\hline Croton & Croton sp. \\
\hline 3-seeded Mercury & Acalypha sp. \\
\hline St. John's wort & Hypericum sp. \\
\hline Slough grass & Spartina pectinata \\
\hline Grass family & Poaceae \\
\hline Smartweed & Polygonum sp. \\
\hline Purslane & Portulaca oleracea \\
\hline Bulrush & Scirpus sp. \\
\hline Sedge family & Cyperaceae \\
\hline Prickly sida & Sida spinosa \\
\hline Campion/catchfly & Silene sp. \\
\hline Ragweed & Ambrosia trifida and Ambrosia sp. \\
\hline Geranium & Geranium sp. \\
\hline
\end{tabular}

(Continued)
TABLE 2 | Continued

\begin{tabular}{ll}
\hline Common name & Scientific name \\
\hline Morning glory & Ipomoea sp. \\
Carpetweed & Mollugo verticillata \\
Evening primrose & Oenothera sp. \\
Sheep sour & Oxalis sp. \\
Verbena & Verbena sp. \\
\hline
\end{tabular}

TABLE 3 | Faunal remains from Cahokia (after Kelly L. S., 1997, p. 84-85).

\begin{tabular}{|c|c|c|}
\hline Mammals & Birds & Fish \\
\hline Squirrel & Grebs & Sturgeon \\
\hline Pocket gopher & Swan & Gar \\
\hline Muskrat & Goose & Bowfin \\
\hline Beaver & Snow/Blue goose & Gizzard shad \\
\hline Canid & Zanada goose & Pike \\
\hline Rabbit & Mallard & Channel catfish \\
\hline Mink & Pintail & Black bullhead \\
\hline Raccoon & Gadwall & Brown bullhead \\
\hline Deer & Widgeon & Yellow bullhead \\
\hline Elk (rare) & Teal & Bullhead \\
\hline \multirow[t]{21}{*}{ Bison (rare) } & Surface-feeding & Catfish \\
\hline & Wood duck & Flathead catfish \\
\hline & Ringneck/lesser & Buffalo sucker \\
\hline & Redhead & Carpsucker \\
\hline & Diving duck & Redhorse \\
\hline & Goldeneye & Chubsucker \\
\hline & Ruddy & Sucker \\
\hline & Merganser & Bass \\
\hline & Sandhill Crane & Sunfish \\
\hline & Coot & Rockbass \\
\hline & Sora & Crappie \\
\hline & Rail & Sunfish family \\
\hline & Willet & White bass \\
\hline & Yellowlegs & Walleye \\
\hline & Plover & Perch \\
\hline & Seagull & Drum \\
\hline & Passenger pigeon & Eel \\
\hline & Turkey & Minnow \\
\hline & Prairie chicken & \\
\hline & Bobwhite & \\
\hline & Hawk & \\
\hline
\end{tabular}

food supply. Crops would be unlikely to fail in both areas. If bottomland fields had too much water (a common problem), upland fields would thrive. Conversely, if rainfall was insufficient, the moist bottomland soils would be more likely to produce a crop than the drier upland soils.

In fact, this strategy has proven beneficial even in modern times. Interviewing farmers who had lived in the area in the 1930s, Chmurny (1973) found distinct strategies underlying long-term failure or success. Those who gambled on maximizing production often failed. They tried to predict yearly moisture 
conditions and concentrated production on either well-watered or well-drained soils within a particular farm. Farmers successful over the long-term divided their risks between well-drained and well-watered soils in the bottom and the uplands. It was a strategy of maximizing one's chances for survival rather than maximizing profit. Missippian farmers would have had similar experiences.

In summary, the people who established Cahokia lived in an environment that provided an exceptional variety of foods, both vegetal and animal. Even so, food security was not assured, and care had to be taken to ensure an adequate supply for the largest concentration of people seen north of Mexico before the nineteenth century. The mix of plant and animal species used changed over time. Maize became widely used late in the region's occupation, while animal use shifted from fish to mammals, and back to fish. These changes coincided with Cahokia's political development and regional settlement patterns, as described below.

\section{SUMMARY: POLITICAL AND METABOLIC DEVELOPMENTS}

Cahokia was a product of the human and societal metabolism made possible by the rich variety of the oily and starchy plants of the Eastern Agricultural Complex (Benson et al., 2007, p. 348; Fritz, 2019). Plant foods were augmented by a variety of fish, birds, and mammals (primarily deer). The terrain of the American Bottom and nearby bluffs and uplands meant that there were diverse environmental zones for people to use. These included fertile bottomlands, the Mississippi River, creeks, backwater lakes formed by former river channels, bluffzone forests, and uplands (Dalan et al., 2003). This variety of plants, animals, and terrain supported both the population and the metropolis.

Cahokia's metabolism, political system, and metropolitan development emerged together. None can be understood without the others. The agricultural productivity of the Eastern Agricultural Complex provided the metabolism that made the Big Bang possible. Since solar energy provides few calories per unit of land, humans have rarely had abundant energy. Human activities and the complexity of societies evolve to make use of whatever energy is available (Tainter, 2011). In the American Bottom, the energy supplied by the plants of the Eastern Agricultural Complex led to the establishment of a metropolis.

The Lohmann phase saw the termination of a system of rural villages, and the transfer of their populations to Cahokia. This coincided with the construction of a planned urban center, including Monk's Mound, the Grand Plaza, and smaller mounds, including Mound 72. All this was done in a period of no more than 50 years. Cahokia became the home of 10,000 to 15,000 people.

The sacrifice and burial of dozens of individuals in Mound 72 indicates that the rulers of Cahokia had unprecedented power. In a subsistence economy dependent on solar energy, prosperity and power come from a combination of land and labor. The burial within Mound 72 of 53 females of reproducing age, most likely slaves, means that Cahokia's rulers were sacrificing future prosperity and power, including their own. They did so as a form of conspicuous display. This act, as much as the other activities undertaken in the Lohmann phase, shows the confidence of Cahokia's elites in their own power and its metabolic basis. It also demonstrates that the institution of slavery existed at Cahokia. For comparison, among the native Illinois at the historic Grand Village of the Kaskaskia, slavery was common, especially of women (Morrissey, 2015, p. 687-689).

The plant food diet seems to have remained unchanged in the Lohmann phase. Use of fish declined, while mammal use (mainly deer) increased proportionately. This may reflect a change in the distribution of population. Fewer people resided in bottomland villages, near fishing locations. More people settled in or near the bluffs and uplands (the Richland Complex), where more deer were to be found, especially within the bluffzone forests.

As population dispersed outward from Cahokia during the Stirling phase, Cahokia's metabolic basis did not immediately change. A three-tiered settlement hierarchy developed in the countryside as the population of Cahokia declined by half. More of the population was living near their agricultural fields, so that the labor cost of transporting food to Cahokia was increased.

During the thirteenth century, population declined in both Cahokia and the countryside. At the same time, plant food diets shifted away from the Eastern Agricultural Complex crops toward more use of maize (Fritz, 2019, p. 127-128). The political and demographic stresses that the region was experiencing required a change in diet, a change to a crop that was more productive but less nutritious. Animal use became more localized and the use of fish increased. People consumed more of the less desirable parts of deer carcasses.

By the end of the thirteenth century, Cahokia had collapsed as a complex metropolis. More and more people left the American Bottom, and it was largely unused until the nineteenth century. As an experiment in complexity, Cahokia had exceeded its metabolic basis.

\section{ENVIRONMENTAL CHANGES}

When investigating the collapse of a complex society, it is best to look for social, political, and economic changes within the society, and changes in its environment. Notwithstanding the palisade, there is no unequivocal evidence that Cahokia's existence was threatened by other societies. There were, however, changes in its biophysical environment.

George Milner notes that Mississippian structures in the American Bottom are rarely found below $125 \mathrm{~m}$. elevation. In historic times land below this elevation was inundated seasonally or year-round, and was valueless unless drained (Milner, 1986, p. 229). Mark Mehrer points out that in the Moorehead phase at Cahokia and in the countryside houses were consistently placed at somewhat higher elevations than previously $(1995, \mathrm{p} .160)$. It has been argued from this that flood levels were increasing and that this would have reduced the area of bottomland suitable for farming and habitation (Milner, 1990, p. 7; Woods, 2004). Major floods occur in the spring, from upstream snow melt and from precipitation in the upper Missouri and/or upper Mississippi basins.

A high volume of wood went into Cahokia's construction and occupation. Lopinot and Woods (1993; Woods, 2004) argue 
that in the Stirling phase wood use came to be increasingly localized and diversified. They suggest that intensified local cutting increased runoff and caused floods to become more frequent, severe, and unpredictable. Milner notes that after 1050 the area experienced rapid soil deposition, and suggests that it was caused by increased runoff from cutting bluff-zone forests (1990, p. 7). More recent research questions these evaluations, since the area had been significantly deforested centuries before (Munoz et al., 2014, p. 501).

There is much uncertainty about such arguments. Larry Benson, for example, suggests that the region was affected by drought, with severe droughts in 140 of 145 years after 1100 (Benson et al., 2007, 2009). A drought from 1276 to 1297 "appears to have substantially impacted the region" (Benson et al., 2007, p. 342). This may have led to the abandonment of the Richland Complex sites along with the agriculture that sustained Cahokia (Benson et al., 2009, p. 476-477). Broxton Bird finds midcontinental droughts after 1200 , and also a possibility of increased flooding in this period (Bird et al., 2017, p. 7).

Munoz notes a prominent floodwater deposit at around 1200 A.D. \pm 80 , and diminished agricultural activity from 1200 to 1350 (Munoz et al., 2014, 2015). Kelly (2008, p. 156) finds a shift to higher landforms in the Moorehead and Sand Prairie phases, perhaps as a response to flooding. Arguing contrariwise, Pompeani asserts that there is no evidence for a large, late Stirling phase flood. The noted flood deposits, rather, represent local erosion (Pompeani et al., 2018, p. 724-725). Munoz et al. (2019), in turn, show that the flood desposit is not local, but rather derived from the Missouri River (Figure 5). Such a flood would cover a large part of the American Bottom. White et al. (2019) argue that a major flood and warm season drought occurred at the same time, which would surely have affected cultivation.

Fecol stanols (organic molecules that originate in the human gut, and persist for centuries in soils) closely track reconstructed population trends in the American Bottom (White et al., 2018). The frequency of these molecules, argue White et al. (2019), support the idea that massive flooding was related to the late twelfth century changes, including population contraction, catastrophic abandonment of some settlements, a decline in mound construction, and the building of the first palisade.

Much work needs to be done to understand Cahokia's environment, and whether changes in the environment were connected to the collapse. The research to date is important, but does not demonstrate that environmental factors caused Cahokia's collapse. If spring flooding was a problem, one solution would be to shift cultivation to the uplands, beyond the reach of flooding. This area was indeed the location of a set of farming villages, the Richland Complex, as discussed above. Yet this is precisely the area that had been abandoned late in Cahokia's history. As for drought, a society that had experienced 140 years of dry conditions will have adapted to such conditions. Drought lasting nearly a century and a half would become normal. Moreover, an environmental condition extending over 140 years does not fully explain the profound changes beginning in the Stirling Phase, nor does it comprehensively explain the collapse of a powerful polity during the Moorehead Phase. The labor required for public works peaked in this phase (Milner,
1998, p. 149), which suggests that agricultural production was not a limiting factor. Neither flooding nor drought can, by themselves, explain the collapse of Cahokia. While Cahokia's environment was of course important, we must turn to social and economic factors to understand the end of Cahokia.

\section{A COMPARATIVE PERSPECTIVE}

The most enigmatic aspect of early Cahokia is the constellation of rapid changes about 1050 A.D. that Pauketat aptly characterizes as the Big Bang (1997, p. 31). Over a short time Cahokia was transformed from an important village to a planned metropolis. Its population grew perhaps ten-fold. Cahokia underwent processes common to the early phases of urbanization. These included the planning and construction of its core, and the transfer of populations from rural agriculture to central public works. The countryside was transformed as well. Rural social structure was atomized-reduced to the most basic element, the household. The horizontal ties of community integration were severed, leaving society to be reconstituted along vertical lines. History may offer few examples of such profound, rapid, system-wide changes.

It is a truism, and one of history's most accurate generalizations, that over the past 12,000 years human societies have shown an almost inexorable tendency to grow more complex. This is puzzling on the surface. Complexity always has a metabolic cost, paid in early societies by human labor (Tainter, 1988). The cost of supporting complex institutions must always have inhibited the development of cultural complexity. Thus, explaining the human trend toward greater complexity is more of a challenge than we customarily think. One of the paradoxes of complexity is that it actually simplifies. Elaboration of structure and emergence of organization simplify and channel behavior. An activity formerly distributed among many components of a social system will, with increased complexity, be concentrated in a specialized component or new hierarchical level. This is the essence of decision-making hierarchies. The benefit of complexity is that it can be deployed as a simplifying, problemsolving strategy, and often is with great success. It is for this reason that ever since the end of the Pleistocene there have been veritable explosions in the complexity of such areas as technology, economics, settlement, sociopolitical organization, and information processing (Tainter, 1988).

Given that complexity both carries costs and yields benefits, it can be analyzed as an economic process, subject to the same constraints as other economic matters. One of these constraints is the marginal utility of complexity. Developing greater complexity is suitable for problem-solving as long as the strategy yields stable or increasing returns. Ultimately and inevitably, though, as economical solutions are progressively exhausted, societies reach the point of declining marginal returns to complexity (Figure 8) (Tainter, 1988). Beyond this point growing more complex yields lower and lower benefits per unit of investment. This is the realm of diminishing returns to complexity. It can be brought about either by growing more complex, or by remaining at a specific level of complexity while the per capita costs of 


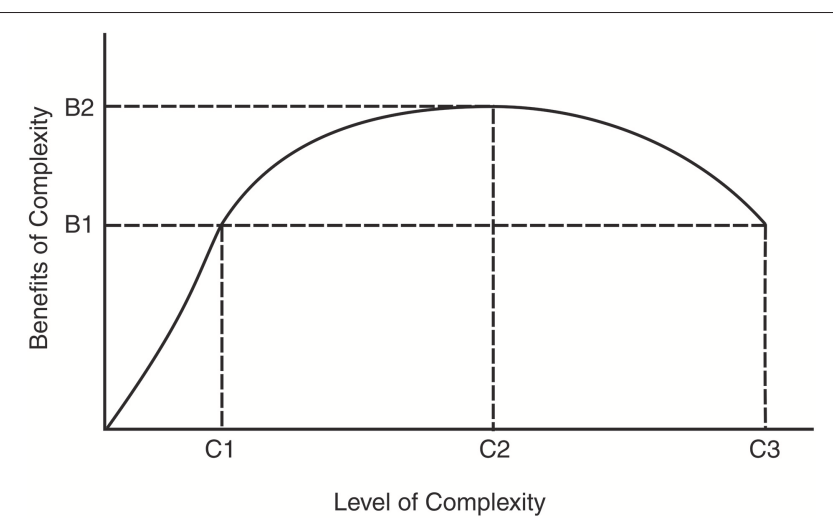

FIGURE 8 | The marginal product of increasing complexity (after Tainter, 1988, p. 119).

complexity increase-as seems to have happened late in Cahokia's development (Milner, 1998, p. 149), as discussed above. Societies that experience this problem for a protracted time will ultimately encounter three options: impoverish the support population, acquire new energy subsidies to pay for complexity, or collapse. These options aren't mutually exclusive: the first and second often do no more than delay the third.

Diminishing returns to complexity make a society vulnerable to collapse through two processes. The first is through simple economic weakness, which leaves a society without sufficient reserves to cope with emergencies (Tainter, 2013). The second is through disaffection of the population, who are called upon to support the higher costs of complexity. Both factors can be seen to have been at work in well-studied cases, such as the collapse of the Western Roman Empire or the Classic Maya (Tainter, 1988).

Several factors are pertinent to understanding the collapse of Cahokia, including the level of public works, the status of the support population, and the extent of vertical differentiation within the elite stratum.

Based on present knowledge we observe that after the initial, massive constructions of the Lohmann phase-Monks Mound and the Grand Plaza-public building continued at a high level during the Stirling phase and into at least early Moorehead. In fact, the labor required for public works peaked in the Moorehead phase (Milner, 1998, p. 149). The palisade and postand-circle monuments were built, then rebuilt over and over. The ordinary mounds of later periods tended to be more massive than those of the Lohmann phase. There were clearly public labor requirements throughout most of Cahokia's duration.

It is significant that later constructions-the palisade and post-and-circle monuments-would have required higher levels of information in their design and building. This is another societal cost, for it indicates the development and transmission of esoteric knowledge, and suggests expansion of midlevel elites specializing in knowledge production. Throughout the countryside there is evidence for yet more midlevel functionaries in nodal sites. These sites came fully into existence during the Stirling phase, and include diversified structures such as mounds, sweat houses, and temples (Emerson, 1997a: 179-184). At Cahokia itself the later construction boom in intermediate-sized mounds suggests expansion in intermediate levels of the hierarchy. This combination of trends indicates both that the hierarchy was differentiating vertically-always a sure way to increase costs-and that the power once consolidated in the paramount was being diffused downward and outward (e.g., Collins, 1997, p. 139; Pauketat, 2004). Phillips (1979) has suggested that one of the factors that often weakens emerging complex societies is the dispersion of income through intermediate hierarchical levels. Expanding the middle levels of a hierarchy increases the overall societal costs to support elite classes, and creates levels of administrators who can block the flow of resources to the top of the hierarchy.

The population trends of the region are probably the most important indicator of all. Population decline is often a correlate of sociopolitical collapse. It can be observed in such collapses as the Roman Empire, the Third Dynasty of Ur, the Abbasid Caliphate, the Hittite Empire, Mycenaean Greece, the southern Lowland Maya, the southern Andes after the fall of Huari, Chaco Canyon, and of course Cahokia (Tainter, 1988, 1999).

In some cases population leveled off or actually began to decline generations to centuries before collapse. In these caseswhich include the Roman Empire, the Maya, the Abbasid Caliphate, perhaps the Western Chou Dynasty, and Cahokiapopulation trends seem to have been a harbinger of collapse (Tainter, 1988, 1999). Cahokia's population trends become especially significant in this light. Through the twelfth and thirteenth centuries the population first declined at Cahokia as it increased throughout the American Bottom, then declined in both the center and the hinterland. During the Moorehead and Sand Prairie phases population declined an average of $1 \%$ per year (Milner, 1990, p. 11). Voluntary emigration from the American Bottom was apparently a major component of this decline. Those remaining had to assume a higher labor burden to support the ongoing public works. The population trend indicates both that the metabolism supporting Cahokia was being weakened, and that disaffection of the population was a component of Cahokia's fall.

There are several collapse cases in which the population decline was surprisingly long-lasting. These areas were for several centuries afterwards either unoccupied or settled sparsely. Wellknown cases include central Anatolia after the Hittite collapse, Mesopotamia after the collapses of the Third Dynasty of Ur and the Abbasid Caliphate, the central Petén of the Maya Lowlands, and the San Juan Basin after the Chacoan collapse. Cahokia was one of these cases, for after its collapse both the site itself and the American Bottom were used for several centuries by no more than a few families at a time (Pauketat and Emerson, 1997, p. 21-22; Emerson, 1997b, p. 54). For such cases it seems particularly worthwhile to investigate whether there was a component of environmental degradation to the processes of collapse and abandonment, so that these regions became unsuitable for dense occupation. This may have been the case in the American Bottom, although evidence does not yet support such a finding. 
Cities grow where people have already settled, which is likely to be the best agricultural land. As noted above, this was the case at Cahokia, which had more of the best land nearby than other locations in the American Bottom (Dalan et al., 2003, p. 85). Such optimal land is converted to urban uses. Population aggregation and continued growth must then be sustained by less productive land (Barthel et al., 2019), or land some distance away (such as the Richland Complex sites, as described above). This forces cities to undertake the cost of transporting food, and creates pressure to cultivate intensively. Intensive cultivation on less desirable land is likely to lead to degradation of the land.

Thus we see characteristic patterns to the collapse of Cahokia: initial centralization and reorganization of the support population, followed by population dispersal and vertical differentiation, a continued high level of public construction, population decline, and collapse. As people left the American Bottom those remaining assumed a higher labor burden per capita to support the hierarchy and its public works. The cost to each individual of supporting the hierarchy grew without any commensurate increase in the hierarchy's outputs. It was a characteristic case of diminishing returns to investment in complex institutions and it made the collapse probable or even inevitable.

\section{A LESSON FOR URBANIZATION}

Any comparison between past and contemporary cities is hampered by the fact that past metropolises were built on solar energy, while contemporary ones depend on fossil fuels. Past cities were constrained ultimately by the cost of land transport. The energy cost of transporting food and other resources by land is so high (Jones, 1964, p. 841-844; Wrigley, 2010, p. 44) that most ancient cities could have only small territories, and be small themselves. Ancient cities could grow to a large size only if they were close enough to a body of water to allow transport by ship (Tainter, 2019). Fossil fuels eliminated this constraint. Thanks to fossil fuels, cities today grow to a size and level of complexity that was previously impossible. Notwithstanding this difference in energy base, ancient cities can give us lessons about the process of urbanization in general.

One important lesson concerns innovation. To be sustained cities must innovate. They must innovate not only at a high rate, but also at an accelerating pace (Bettencourt et al., 2007). With the constellation of developments around the Big Bang, it is clear that early Cahokia was highly innovative. The reorganization of rural life, the movement of people to Cahokia, the creation of an unprecedented metropolis, and the planning and construction of central Cahokia point to a society (or at least an elite stratum and planners within that society) that was highly creative. Nothing like Cahokia had been developed before north of Mexico, and nothing on this scale would be created again by native people. After the Big Bang, the creation of the Richland Complex, and the return of agricultural labor to the countryside during the Stirling phase, show that the rulers of Cahokia continued to be highly innovative. A lack of innovation cannot be suggested as the reason for Cahokia's collapse.
Urban plans that do not acknowledge constraints are bound to fail, or to present continuous challenges that take unending inputs of resources and innovations to address. The important question therefore becomes: Were Cahokia's innovative energies directed to the right purposes? This brings us to the most important question: Why did Cahokia emerge and develop as it did? The answer is not clear. Complex societies sometimes develop because similar societies exist nearby (Renfrew, 1982). This was not the case with Cahokia. No comparable society developed north of Mexico. Notwithstanding the construction of the palisade, there is no evidence that Cahokia was mortally threatened by external enemies. Although Cahokia could have had markets, cities are not needed for that purpose. Cahokia does not appear to have served a mercantile function. There is no evidence that Cahokia provided any material resources or services to the countryside. To the contrary, the flow of resources went from the countryside to Cahokia.

It appears, therefore, that Cahokia was an elite construct, created solely to aggregate and control the rural population and its resources. Its lesson for today concerns the challenges of topdown urbanism. In this one is reminded of Brasilia, the city created out of the Amazon to administer the Brazilian state. As Scott has described, Brasilia works because its malfunctioning planned parts are augmented by functional unplanned parts and the people who live in them (1998, p. 117-130).

There are both advantages and disadvantages to top-down urban design. Advantages include (1) legibility of the cityscape and control of the population (Scott, 1998); (2) facilitating transportation; (3) sanitation and water supply; as well as (4) reproducibility and the ability quickly to rebuild, if necessary (Tainter and Taylor, 2014). Disadvantages and costs include (1) increasing complexity and diminishing returns to complexity (Tainter and Taylor, 2014); (2) continuous costs of administration and provision of services; (3) higher metabolism and energy costs per capita; and (4) a need for high and accelerating rates of innovation (Bettencourt et al., 2007). In the case of Cahokia it is hard to see how urbanization advantaged the population as a whole ${ }^{1}$. As for disadvantages, the creation of Cahokia meant (1) the abandonment of ancestral villages and the social life of those communities; (2) aggregation of the population with concomitant problems of conflict, sanitation, and trash disposal; (3) increased interpersonal conflict; (4) use of more distant, sub-prime fields to grow food, with greater transport costs; (5) subjection of the support population to monitoring, control, and labor; (6) higher metabolism and energy costs per capita; and (7) environmental damage, at least in the bluff zone forests. Complexity is always a benefit/cost tradeoff (Tainter, 1988). At Cahokia, the benefits of complexity accrued at the top of the hierarchy in the form of power, control, and security. The costs of complexity were paid at the bottom of the hierarchy in the form of increased labor, loss of autonomy, and a declining resource base. In other historical cases, collapses have been a result of economic

\footnotetext{
${ }^{1}$ Some authors see Cahokia as having had a centralizing ideological function (e.g., Pauketat, 2004: 113-119, 145), which is interpreted here as a means of controlling the population rather than an advantage to it.
} 
weakness from diminishing returns to complexity, combined with external challenges and/or disaffection of the population (Tainter, 1988). While we cannot point to a single factor or challenge that caused Cahokia's collapse, the fact of its collapse is no surprise.

\section{DATA AVAILABILITY STATEMENT}

The datasets analyzed in this manuscript are not publicly available. Requests to access the datasets should be directed to the authors cited herein.

\section{REFERENCES}

Alt, S. (2002). Identities, traditions, and diversity in Cahokia's uplands. Midcont. J. Archaeol. 27, 217-235. doi: 10.2307/20708178

Ambrose, S. H., Buikstra, J., and Kreuger, H. W. (2003). Status and gender differences at Mound 72, Cahokia, revealed by isotopic analysis of bone. J. Anthropol. Archaeol. 22, 217-226. doi: 10.1016/S0278-4165(03)00036-9

Anderson, D. G. (1994). The Savannah River Chiefdoms: Political Change in the Late Prehistoric Southeast. Tuscaloosa, AL: University of Alabama Press.

Barthel, S., Isendahl, C., Vis, B. N., Drescher, A., Evans, D. L., and van Timmeren, A. (2019). Global urbanization and food production in direct competition for land: leverage places to mitigate impacts on DSG2 and on the earth system. Anthropocene Rev. 6, 71-97. doi: 10.1177/2053019619856672

Benson, L. V., Berry, M. S., Jolie, E. A., Spangler, J. D., Stahle, D. W., and Hattori, E. A. (2007). Possible impacts of early-11th-, middle 12th-, and late-13th-century droughts on western Native Americans and the Mississippian Cahokians. Q. Sci. Rev. 26, 336-350. doi: 10.1016/j.quascirev.2006.08.001

Benson, L. V., Pauketat, T. R., and Cook, E. A. (2009). Cahokia's boom and bust in the context of climate change. Am. Antiq. 74, 467-483. doi: $10.1017 /$ S000273160004871X

Bettencourt, L. M. A., Lobo, J., Helbing, D., Kuhnert, C., and West, G. B. (2007). Growth, innovation, scaling, and the pace of life in cities. Proc. Natl. Acad. Sci. U.S.A. 104, 7301-7306. doi: 10.1073/pnas.0610172104

Bird, B. W., Wilson, J. J., Gilhooly III, W. P., Steinman, B. A., and Stamps, L. (2017). Midcontinental Native American population dynamics and late holocene hydroclimate extremes. Sci. Rep. 7:41628. doi: 10.1038/srep 41628

Brugam, R. B., and Munoz, S. E. (2018). A 1600-year record of human impacts on a floodplain lake in the mississippi river valley. J. Paleolimnol. 60, 445-460. doi: 10.1007/s10933-018-0033-0

Chmurny, W. W. (1973). The ecology of the middle Mississippian occupation of the American bottom (Ph.D. dissertation), University of Illinois, UrbanaChampaign, IL, United States.

Collins, J. M. (1997). "Cahokia settlement and social structures as viewed from the ICT-II," in Cahokia: Domination and Ideology in the Mississippian World, eds T. R. Pauketat and T. E. Emerson (Lincoln, NE: University of Nebraska Press), 124-140.

Dalan, R. A. (1997). "The construction of Mississippian Cahokia," in Cahokia: Domination and Ideology in the Mississippian World, eds T. R. Pauketat and T. E. Emerson (Lincoln, NE: University of Nebraska Press), 89-102.

Dalan, R. A., Holley, G. R., Woods, W. I., Wetters, H. W. Jr., and Koepke, J. A. (2003). Envisioning Cahokia: A Landscape Perspective. DeKalb, IL: Northern Illinois University Press.

Emerson, T. E. (1997a). "Reflections from the countryside on Cahokian hegemony," in Cahokia: Domination and Ideology in the Mississippian World, eds T. R. Pauketat and T. E. Emerson (Lincoln, NE: University of Nebraska Press), 167-189.

Emerson, T. E. (1997b). Cahokia and the Archaeology of Power. Tuscaloosa, AL: University of Alabama Press.

Fowler, M. L. (1969). "The Cahokia site," in Explorations Into Cahokia Archaeology, ed M. L. Fowler (Urbana, IL: Illinois Archaeological Survey Bulletin), 1-30.

\section{AUTHOR CONTRIBUTIONS}

The author confirms being the sole contributor of this work and has approved it for publication.

\section{ACKNOWLEDGMENTS}

I am pleased to thank Sergio Ulgiati for the invitation to prepare this paper, Temis Taylor for comments on it, Lynne Goldstein for recommending literature on fauna consumed at Cahokia, and three reviewers.

Fowler, M. L. (1989). The Cahokia Atlas: A Historical Atlas of Cahokia Archaeology. Urbana, IL: cIllinois Historic Preservation Agency, Studies in Illinois Archaeology.

Fowler, M. L. (1991). "Mound 72 and early Mississippian at Cahokia," in New Perspectives on Cahokia: Views From the Periphery, ed J. B. Stoltman (Madison, WI: Prehistory Press), 1-28.

Fritz, G. J. (2019). Feeding Cahokia: Early Agriculture in the North American Heartland. Tuscaloosa, AL: University of Alabama Press.

Hall, R. L. (1991). "Cahokia identity and interaction models of Cahokia Mississippian," in Cahokia and the Hinterlands: Middle Mississippian Cultures of the Midwest, eds T. E. Emerson and R. B. Lewis (Urbana, IL: University of Illinois Press), 3-34

Harn, A. D. (1971). "An archaeological survey of the American Bottoms in Madison and St. Clair Counties, Illinois," in Archaeological Surveys of the American Bottoms and Adjacent Bluffs, Illinois, Vol. 21, eds P. J. Munson and A. D. Harn (Urbana, IL: Illinois State Museum Reports of Investigations), 19-39.

Jones, A. H. M. (1964). The Later Roman Empire: A Social, Economic and Administrative Survey. Norman, OK: University of Oklahoma Press.

Kelly, J. E. (1997). "Stirling-phase sociopolitical activity at East St. Louis and Cahokia," in Cahokia: Domination and Ideology in the Mississippian World, eds T. R. Pauketat and T. E. Emerson (Lincoln, NE: University of Nebraska Press), 141-166.

Kelly, J. E. (2008). “Contemplating Cahokia's collapse," in Global Perspectives on the Collapse of Complex Systems, eds J. A. Railey and R. M. Reycraft (Albuquerque, NM: Maxwell Museum of Anthropology), 147-168.

Kelly, L. S. (1997). "Patterns of faunal exploitation at Cahokia," in Cahokia: Domination and Ideology in the Mississippian World, eds T. R. Pauketat and T. E. Emerson (Lincoln, NE: University of Nebraska Press), 334-367.

Kelly, L. S. (2001). "A Case of ritual feasting at the Cahokia site," in Feasts: Archaeological and Ethnographic Perspectives on Food, Politics, and Power, eds M. Dietler and B. Hayden (Washington, DC: Smithsonian Institution Press), 334-367.

Lopinot, N. H., and Woods, W. I. (1993). "Wood overexploitation and the collapse of Cahokia," in Foraging and Farming in the Eastern Woodlands, ed C. M. Scarry (Gainesville, FL: University Press of Florida), 206-231.

Mehrer, M. W. (1995). Cahokia's Countryside: Household Archaeology, Settlement Patterns, and Social Power. De Kalb, IL: Northern Illinois University Press.

Middleton, G. D. (2017). Understanding Collapse: Ancient History and Modern Myths. Cambridge: Cambridge University Press. doi: 10.1017/97813165 84941

Milner, G. R. (1986). Mississippian period population density in a segment of the Central Mississippi River Valley. Am. Antiq. 51, 227-238. doi: 10.2307/279938

Milner, G. R. (1990). The late prehistoric Cahokia cultural system of the Mississippi River Valley: foundations, florescence, and fragmentation. J. Prehistory 4, 1-43. doi: $10.1007 / \mathrm{BF} 00974818$

Milner, G. R. (1991). "American Bottom Mississippian Culture: internal development and external relations," in New Perspectives on Cahokia: Views From the Periphery, ed J. B. Stoltman (Madison, WI: Prehistory Press), 29-47.

Milner, G. R. (1998). The Cahokia Chiefdom: The Archaeology of a Mississippian Society. Washington, DC: Smithsonian Institution Press. 
Morrissey, R. M. (2015). The power of the ecotone: Bison, slavery, and the rise and fall of the Grand Village of the Kaskaskia. J. Am. History 102, 667-692. doi: 10.1093/jahist/jav514

Muller, J. (1997). Mississippian Political Economy. New York, NY: Plenum Press. doi: 10.1007/978-1-4899-1846-8

Munoz, S. E., Giosan, L., Bluszlajn, J., Rankin, C., and Stinchcomb, G. E. (2019). Radiogenic fingerprinting reveals the anthropogenic and buffering controls on sediment dynamics of the Mississippi River system. Geology 47, 271-274. doi: 10.1130/G45194.1

Munoz, S. E., Gruley, K. E., Massie, A., Fike, D., A., Schroeder, S., et al. (2015). Cahokia's emergence and decline coincided with shifts of flood frequency on the Mississippi River. Proc. Natl. Acad. Sci. U.S.A. 112, 6319-6324. doi: 10.1073/pnas.1501904112

Munoz, S. E., Schroeder, S., Fike, D. A., and Williams, J. W. (2014). A record of sustained prehistoric and historic land use from the Cahokia region, Illinois, USA. Geology 42, 499-502. doi: 10.1130/G35541.1

Munson, P. J. (1971). “An Archaeological survey of the Wood River terrace and adjacent bottoms and bluffs in Madison County, Illinois," in Archaeological Surveys of the American Bottoms and Adjacent Bluffs, Illinois, eds P. J. Munson and A. D. Harn (Urbana, IL: Illinois State Museum Reports of Investigations), 1-17.

Pauketat, T. R. (1994). The Ascent of Chiefs: Cahokia and Mississippian Politics in Native North America. Tuscaloosa, AL: University of Alabama Press.

Pauketat, T. R. (1997). "Cahokian political economy," in Cahokia: Domination and Ideology in the Mississippian World, eds T. R. Pauketat and T. E. Emerson (Lincoln, NE: University of Nebraska Press), 30-51.

Pauketat, T. R. (2003). Resettled farmers and the making of a Mississippian polity. Am. Antiq. 68, 39-66. doi: 10.2307/3557032

Pauketat, T. R. (2004). Ancient Cahokia and the Mississippians. Cambridge: Cambridge University Press.

Pauketat, T. R., and Emerson, T. E. (1997). "Introduction: domination and ideology in the Mississippian world," in Cahokia: Domination and Ideology in the Mississippian World, eds T. R. Pauketat and T. E. Emerson (Lincoln, NE: University of Nebraska Press), 1-29.

Pauketat, T. R., Kelly, L. S., Fritz, G. J., Lopinot, N. H., Elias, S., and Hargrave, E. (2002). The residues of feasting and public ritual at early Cahokia. Am. Antiq. 67, 257-279. doi: 10.2307/2694566

Pauketat, T. R., and Lopinot, N. H. (1997). "Cahokian population dynamics," in Cahokia: Domination and Ideology in the Mississippian World, eds T. R. Pauketat and T. E. Emerson (Lincoln, NE: University of Nebraska Press), 103-123.

Phillips, D. A. (1979). The growth and decline of states in Mesoamerica. J. Steward Anthropol. Soc. 10, 137-159.

Pompeani, D. P., Hillman, A. L., Finkenbinder, M. S., Bain, D. J., Correa-Metrio, A., Pompeani, K., et al. (2018). The environmental impact of a pre-Columbian city based on geochemical insights from lake sediment cores recovered near Cahokia. Quat. Res. 91, 714-728. doi: 10.1017/qua.2018.141

Renfrew, C. (1982). "Polity and power: interaction, intensification and exploitation," in An Island Polity: The Archaeology of Exploitation on
Melos, eds C. Renfrew and M. Wagstaff (Cambridge: Cambridge University Press), 264-290.

Scott, J. C. (1998). Seeing Like a State: How Certain Schemes to Improve the Human Condition Have Failed. New Haven, CT: Yale University Press.

Slater, P. A., Kedman, K. M., and Emerson, T. E. (2014). Immigrants at the Mississippian polity of Cahokia: strontium isotope evidence for population movement. J. Archaeol. Sci. 44, 117-127. doi: 10.1016/j.jas.2014.01.022

Tainter, J. A. (1988). The Collapse of Complex Societies. Cambridge: Cambridge University Press.

Tainter, J. A. (1999). "Post-collapse societies," in Companion Encyclopedia of Archaeology, eds G. Barker and A. Grant (London: Routledge), 988-1039.

Tainter, J. A. (2011). Energy, complexity, and sustainability: a historical perspective. Environ. Innov. Soc. Transit. 1, 89-95. doi: 10.1016/j.eist.2010.12.001

Tainter, J. A. (2013). Energy and existential sustainability: the role of reserve capacity. J. Environ. Acc. Manag. 1, 213-228. doi: 10.5890/JEAM.2013.08.001

Tainter, J. A. (2019). "Scale and metabolism in ancient cities," in Understanding Urban Ecology: An Interdisciplinary Systems Approach, eds M. H. P. Hall and S. B. Balogh (Cham: Springer Nature Switzerland), 85-99.

Tainter, J. A., and Taylor, T. G. (2014). Complexity, problem-solving, sustainability and resilience. Build. Res. Inf. 42, 168-181. doi: 10.1080/09613218.2014.850599

White, A. J., Stevens, L. R., Lorenzi, V., Munoz, S. E., and Lipo, C. P. (2018). An evaluation of fecol stanols as indicators of population change at Cahokia, Illinois. J. Archaeol. Sci. 93, 129-134. doi: 10.1016/j.jas.2018.03.009

White, A. J., Stevens, L. R., Lorenzi, V., Munoz, S. E., Schroeder, S., Cao, A., et al. (2019). Fecal stanols show simultaneous flooding and seasonal precipitation change correlate with Cahokia's population decline. Proc. Natl. Acad. Sci. U.S.A. 116, 5461-5466. doi: 10.1073/pnas. 1809400116

Woods, W. I. (2004). Population nucleation, intensive agriculture, and environmental degradation: the Cahokia example. Agric. Hum. Values 21, 255-261. doi: 10.1023/B:AHUM.0000029398.01906.5e

Woods, W. I., and Holley, G. R. (1991). "Upland Mississippian settlement in the American Bottom region," in Cahokia and the Hinterlands: Middle Mississippian Cultures of the Midwest, eds T. E. Emerson and R. B. Lewis (Urbana, IL: University of Illinois Press), 46-60.

Wrigley, E. A. (2010). Energy and the English Industrial Revolution. Cambridge: Cambridge University Press. doi: 10.1017/CBO9780511779619

Young, B., and Fowler, M. (2000). Cahokia: The Great American Metropolis. Urbana, IL: University of Illinois Press.

Conflict of Interest: The author declares that the research was conducted in the absence of any commercial or financial relationships that could be construed as a potential conflict of interest.

Copyright (C) 2019 Tainter. This is an open-access article distributed under the terms of the Creative Commons Attribution License (CC BY). The use, distribution or reproduction in other forums is permitted, provided the original author(s) and the copyright owner(s) are credited and that the original publication in this journal is cited, in accordance with accepted academic practice. No use, distribution or reproduction is permitted which does not comply with these terms. 